\section{A study on the protective effect of bone marrow derived mesenchymal stem cells on chronic renal failure in rats}

\author{
Mohamed Talaat Abd El Aziz, \\ Hazem Atta, ${ }^{1}$ Sohair Mahfouz, ${ }^{2}$ \\ Hanaa Mohamed Yassin, ${ }^{3}$ \\ Laila Ahmed Rashed, ${ }^{1}$ Dina Sabry, ${ }^{1}$ \\ Zienab Abdel Wahab, ${ }^{3}$ Fatma Taha, ${ }^{1}$ \\ Ghada Abdel Aziz, ${ }^{4}$ \\ Abeer Moustafa El Sayed, ${ }^{5}$ \\ Mohamed Sayed ${ }^{3}$ \\ 'Department of Medical Biochemistry, \\ Unit of Biochemistry and Molecular \\ Biology; '2Department of Pathology; \\ ${ }^{3}$ Department of Physiology Faculty of \\ Medicine, Cairo University; ${ }^{4}$ Department \\ of Medical Biochemistry, Faculty of \\ Medicine, Bani Sweif University; \\ ${ }^{5}$ Department of Pathology, National \\ Cancer Institute, Cairo University, Egypt
}

\section{Abstract}

Chronic renal failure (CRF) is a common disease with high morbidity and mortality. The inadequacy of current treatment modalities and insufficiency of donor organs for cadaveric transplantation have driven a search for improved methods of dealing with renal failure. This raises the concept of cell-based therapy using mesenchymal stem cells (MSCs). The purpose of this work is to evaluate the effect of MSCs in rats with CRF and to detect the level of B-cell lymphoma 2 (Bcl-2) and basic fibroblast growth factor (bFGF) as possible antiapoptotic and anti-inflammatory paracrine mediators of MSCs action. This study was carried on female albino rats, which were divided into 3 groups, control group, CRF group and CRF/MSCs group. MSCs were derived from bone marrow of male albino rats and were characterized morphologically and by RT-PCR for CD29. Serum urea, creatinine, Na, $\mathrm{K}$, systolic blood pressure and 24-hour urinary albumin were estimated for all groups, Y-chromosome gene (Sry) was detected by PCR in renal tissue. Also Bcl-2 and bFGF were examined by RT-PCR in renal tissue of all studied groups and the kidney was examined pathologically. The results of this work showed that CRF rats receiving MSCs showed significantly lowered serum urea, creatinine and urinary albumin levels compared to the CRF group. Also improvement of serum $\mathrm{Na}$ and $\mathrm{K}$ was observed in CRF/MSCs group compared to CRF group. As regard Bcl-2 and bFGF they were highly expressed in renal tissue of CRF/MSCs group compared to the CRF group. The (Sry) gene was detected by PCR in the renal tissue of CRF/MSCs group. These results demonstrate a potential of MSCs to ameliorate the kidney function in rats with CRF possibly through the antiapoptotic and anti-inflammatory paracrine mediators of MSCs.

\section{Introduction}

Chronic renal failure (CRF) is a common disease with high morbidity and mortality. Dysfunction and necrosis of renal tubular epithelial cells is the most common injury in chronic renal failure occurring after ischemic or toxic challenge of the kidney. ${ }^{1}$

There is growing recognition that the disease state arising from renal failure is the result of more than just the loss of blood volume regulation, small solute, and toxin clearance that are replaced by conventional dialysis therapy. ${ }^{2}$ The kidney's role in reclamation of metabolic substrates, synthesis of glutathione, and free radical scavenging enzymes, gluconeogenesis, ammoniagenesis, catabolism of peptide hormones and growth factors, and the production and regulation of multiple cytokines critical to inflammation and immunological regulation are not addressed by current treatment modalities. ${ }^{3}$

Thus, there is considerable drive to develop improved therapies for renal failure with the capacity to replace a wider range of the kidney's functions, thereby reducing morbidity, mortality, and the overall economic impact associated with this condition. Such an ambition lies beyond the reach of conventional medicine, with its mainly monofactorial approach to the treatment of disease. Into this breach steps the nascent and expanding field of cell therapy, which offers the promise of harnessing the native abilities of the cell, endowed to it by a billion years of evolution. ${ }^{4}$

During the past several years, a great deal of attention has been focused on the plasticity of bone marrow-derived stem cells. Recent studies have demonstrated that bone marrowderived stem cells have the ability to cross lineage boundaries and to form functional components of other tissues. . $^{5.8}$

The possibility that bone marrow-derived stem cells might functionally contribute to the renal tubule regeneration is still a matter of debate. Bone marrow progenitor's cells from chronic renal failure rats showed no capacity for in vitro proliferation. ${ }^{9}$ Three studies have demonstrated that when female kidneys were transplanted into male recipients, $Y$ chromosome-bearing cells were found in the transplanted kidney; ${ }^{10-12}$ however, in two of the studies these cells showed only minor contribution in the healing process, as they were found only
Correspondence: Dina Sabry, Medical Biochemistry and Molecular Biology. Faculty of Medicine, Cairo University, Egypt.

Tel. +2.0111200200 - Fax: +2.02 .23632297 .

E-mail: dinnasabry69@yahoo.com

Key words: chronic renal failure, mesenchymal stem cells, experimental rats.

Received for publication: 13 May 2011.

Revision received: 24 July 2011.

Accepted for publication: 27 July 2011.

This work is licensed under a Creative Commons Attribution NonCommercial 3.0 License (CC BYNC 3.0).

(C) Copyright M.T.A. El Aziz et al., 2011

Licensee PAGEPress, Italy

Stem Cell Studies 2011; 1:e11

doi:10.4081/scs.2011.e11

to affect $1 \%$ of the examined tubules. The mechanism mediating the protective effects of MSCs might be primarily paracrine, as implied by their demonstrated expression of several growth factors such as hepatocyte growth factor (HGF), vascular endothelial growth factor (VEGF) and insulin like growth factor-1 (IGF1), these factors improve the renal function through their antiapoptotic, mitogenic and other cytokine actions. Also MSCs down regulate the proinflammatory cytokines IL-1- $\beta$, TNF- $\alpha$, and IFN- $\gamma$, as well as iNOS and up regulate the anti-inflammatory and organ-protective IL-10, as well as basic fibroblast growth factor (bFGF), transforming growth factor alpha (TGF- $\alpha$ ) and antiapoptotic Bc1-2. These beneficial paracrine actions are elicited early and late after onset of CRF. ${ }^{13}$ Based on the above-mentioned knowledge, the present study aimed to detect the effect of MSCs in rats with CRF, and to detect the level of Bcl-2 and bFGF as possible antiapoptotic and anti-inflammatory paracrine mediators of MSCs action.

\section{Materials and Methods}

\section{Preparation of bone marrow- \\ derived mesenchymal stem cell}

Bone marrow was harvested by flushing the tibiae and femurs of 6-week-old male white albino rats with Dulbecco's modified Eagle's medium (DMEM, GIBCO/BRL, Invitrogen Corp., Carlsbad, CA, USA) supplemented with $10 \%$ fetal bovine serum (GIBCO/BRL). Nucleated cells were isolated with a density gradient [Ficoll/Paque (Pharmacia, GE Healthcare, Pollards Wood, UK)] and resuspended in complete culture medium supplemented with $1 \%$ penicillin-streptomycin 
(GIBCO/BRL). Cells were incubated at $37^{\circ} \mathrm{C}$ in $5 \%$ humidified $\mathrm{CO}_{2}$ for 12-14 days as primary culture or upon formation of large colonies. When large colonies developed $(80-90 \%$ confluence), cultures were washed twice with phosphate buffer saline (PBS) and the cells were trypsinized with $0.25 \%$ trypsin in $1 \mathrm{mM}$ EDTA (GIBCO/BRL) for $5 \mathrm{~min}$ at $37^{\circ} \mathrm{C}$. After centrifugation, cells were resuspended with serum-supplemented medium and incubated in $50 \mathrm{~mL} / 25 \mathrm{~cm}^{2}$ culture flask (Falcon, BD Biosciences, Franklin Lakes, NJ, USA). The resulting cultures were referred to as first-passage cultures. ${ }^{14}$ MSCs in culture were characterized by their adhesiveness and fusiform shape Also CD29 gene expression by reverse transcription polymerase chain reaction (RTPCR) was detected as a marker of MSCs. ${ }^{15}$ Other methods for MSCs characterization were done in previous published studies. ${ }^{16-18}$ All animal experiments received approval from the institutional animal care committee.

\section{Labeling of mesenchymal stem cells by green fluorescent protein}

MSCs were harvested during the $4^{\text {th }}$ passage and were labeled with green fluorescent protein (GFP) using monster green fluorescent protein vector and transfast tranfection reagent kit (Promega, Madison, WI, USA). For imaging GFP of MSCs, unstained slides were directly analyzed by confocal laser microscopy (LSM 510, Carl Zeiss, Oberkochen, Germany) incorporating two lasers ( $\mathrm{Ar}$ and $\mathrm{HeNe}$ ) equipped with an inverted Axiovert $100 \mathrm{M}$ microscope. Confocal fluorescence images were taken using a $20 \times$ Plan-Neofluar objective (numerical aperture (NA), 0.5) and a $40 \times$ Plan-Neofluar objective (NA 0.75). To visualize GFP fluorescence, excitation from the 488-nm Ar laser line and emission passing through a band-pass 505-530 filter, which passes wavelengths of $505-530 \mathrm{~nm}$ to the detector, were used. ${ }^{19}$ Unstained paraffine embedded sections have been examined by an Immunofluorostaining method for detection of fluorescence, which served as counterstaining in this method. ${ }^{20}$

\section{Chronic renal failure model and mesenchymal stem cells adminis- tration}

All experimental procedures were performed according to the guidelines for the care and use of animals established by the animal unit in Faculty of Medicine, Cairo University. Thirty inbred strain of white albino female rats, 8 weeks old, weighing between 150 and $200 \mathrm{~g}$ were used in this study. They were inbred and maintained in an air-conditioned animal house with specific pathogen-free conditions, and were subjected to a 12:12-h daylight/darkness and allowed unlimited access to chow and water. The morphological and behavioral changes of rats were monitored every day.

Rats were divided into the following groups:

Control group: involves 10 healthy rats, CRF group: 20 rats that underwent modified $5 / 6$ nephrectomy were anaesthetized with sodium thiopental by intramuscular injection. Laparotomy was done followed by surgical excision of one kidney and cautery of the other to excise $2 / 3$ of its tissue. ${ }^{21}$ The wound was then sealed by continuous $6 / 0$ stitches in 2 layers. Finally, antibiotic ointment (teramycin) and powder (neomycin) were applied to the wound. CRF was determined by elevated blood creatinine then this group was randomly divided into; CRF/MSCs group: 10 rats infused with a single dose of syngenic MSCs $1 \times 10^{6} 22$ cells per rat (intravenous route) in rat tail vein; CRF group: 10 rats were infused with the same volume of saline and serve as a control. After 4 weeks from administration of MSCs, 24 hours urine samples were collected using specialized wire mesh cages and venous blood was collected from the retro-orbital vein. Arterial blood pressure was measured by rat-tail cuff method using an electronic electro sphygmomanometer after the rat was pre warmed to $37^{\circ} \mathrm{C}$ for 15 min. The average of 3 pressure readings was recorded for each measurement while the animals were quietly resting. Then all rats were sacrificed with $\mathrm{CO}_{2}$ narcosis, and kidney tissue was harvested for analysis.

\section{Analysis of kidney histopathology}

Kidney samples were collected into PBS and fixed overnight in $40 \mathrm{~g} / \mathrm{L}$ paraformaldehyde in PBS at $4^{\circ} \mathrm{C}$. Serial 5 - $\mu \mathrm{m}$ sections the kidneys were stained with hematoxylin and eosin (HE) and Masson Trichrome (MT) and were scored histopathologically according to Lloberas et $a l .{ }^{23}$ Other sections were unstained for fluorescent examination.

\section{Polymerase chain reaction detec- tion of male-derived mesenchymal stem cells}

Genomic DNA was prepared from kidney tissues homogenate of the rats in each group using Wizard ${ }^{\circledR}$ Genomic DNA purification kit (Promega, Madison, WI, USA). The presence or absence of the sex determination region on the Y chromosome male (Sry) gene in recipient female rats was assessed by PCR. Primer sequences for Sry gene (forward CATCGAAGGGTTAAAGTGCCA-3., reverse 5.-ATAGTGTGTAG-GTTGTTGTCC-3.) were obtained from published sequences ${ }^{24,25}$ and amplified a product of $104 \mathrm{bp}$. The PCR conditions were as follows: incubation at $94^{\circ} \mathrm{C}$ for $4 \mathrm{~min} ; 35$ cycles of incubation at $94^{\circ} \mathrm{C}$ for $50 \mathrm{~s}, 60^{\circ} \mathrm{C}$ for $30 \mathrm{~s}$, and $72^{\circ} \mathrm{C}$ for $1 \mathrm{~min}$; with a final incubation at $72^{\circ} \mathrm{C}$ for $10 \mathrm{~min}$. PCR products were separated using $2 \%$ agarose gel electrophoresis and stained with ethidium bromide. Positive (male white albino rat genomic DNA) negative (female white albino rat genomic DNA) controls were included in each assay.

\section{Polymerase chain reaction detec- tion of bFGF and $\mathrm{Bcl}-2$ gene expression and quantification}

Total RNA was extracted from kidney tissue homogenate using RNeasy Purification Reagent (Qiagen Inc., Valencia, CA, USA). cDNA was generated from $5 \mu \mathrm{g}$ of total RNA extracted with $1 \mu \mathrm{L}(20 \mathrm{pmol})$ antisense primer of each gene and $0.8 \mu \mathrm{L}$ superscript AMV reverse transcriptase for $60 \mathrm{~min}$ at $37^{\circ} \mathrm{C}$. For PCR, $4 \mu \mathrm{L}$ cDNA were incubated with $30.5 \mu \mathrm{L}$ water, $4 \mu \mathrm{L} 25 \mathrm{mM} \mathrm{MgCl}_{2}, 1 \mu \mathrm{L}$ dNTPs $(10 \mathrm{mM})$, $5 \mu \mathrm{L}$ 10xPCR buffer, $0.5 \mu \mathrm{L}(2.5 \mathrm{U})$ Taq polymerase and $2.5 \mu \mathrm{L}$ of each primer containing 10 pmol. Primer sequences of Bcl-2 and bFGF were as follows respectively (forward 5'- CTGAGCTGACCTTGGAGC -3', 5'-GGAGGGCAC TTCCTGAG-3', reverse 5'- GACTCCAGCCACAAAGATG 3', 5'- GCCTGGCATCACGACT-3'). The reaction mixture was subjected to 40 cycles of PCR amplification as follows: denaturation at $95^{\circ} \mathrm{C}$ for $1 \mathrm{~min}$, annealing at $67^{\circ} \mathrm{C}$ for $1 \mathrm{~min}$ and extension at $72^{\circ} \mathrm{C}$ for $2 \mathrm{~min}$. UV transilluminator visualized the PCR products after separation on $1.5 \%$ agarose gel electrophoresis. DNA band density quantification was done using gel documentation system (BioDoc Analyze digital - digital gel documentation and professional gel analysis - Göttingen, Germany). The quality of RNA and the validity of the amplifications were determined by amplification of $\beta$-actin for the specimens. ${ }^{26}$

\section{Polymerase chain reaction detec- tion of CD29 gene expression}

Total RNA was extracted from cells using RNeasy Purification Reagent (Qiagen, Valencia, CA), and then a sample $(1 \mu \mathrm{g})$ was reverse transcribed with AMV reverse transcriptase (RT) for 30 minutes at $42^{\circ} \mathrm{C}$ in the presence of oligo-dT primer. PCR was performed using specific primers (UniGene Rn.25733) forward: 5'-AATGTTTCAGTGCAGAGC-3' and reverse: 5'-TTGGGAT GATGTCGGGAC-3'. PCR was performed for 35 cycles, with each cycle consisting of denaturation at $95^{\circ} \mathrm{C}$ for 30 seconds, annealing at $55^{\circ} \mathrm{C}$ to $63^{\circ} \mathrm{C}$ for 30 seconds, and elongation at $72^{\circ} \mathrm{C}$ for $1 \mathrm{~min}$, with an additional 10-min incubation at $72^{\circ} \mathrm{C}$ after completion of the last cycle. The PCR product was separated by electrophoresis through a $1 \%$ agarose gel, stained, and photographed under ultraviolet light. ${ }^{27}$

\section{Polymerase chain reaction detec- tion of $\beta$-actin}

The presence of RNA in all tissues was 
assessed by analysis of $\beta$-actin, which is a house-keeping gene. $\beta$-actin primers (forward 5'-TGTTGTCCCTGTATGCCTCT-3', reverse 5'TAATGTCACGCACGATTTCC-3') were designed from GenBank (accession no. J00691) and amplified a product of $206 \mathrm{bp}$. . $^{14,15}$

\section{Biochemical assessment}

Level of 24 hour urinary albumin and serum creatinine, urea, $\mathrm{Na}$ and $\mathrm{K}$ were assessed using conventional available kit.

\section{Statistical analysis}

Data are expressed as mean \pm SD. Significant differences were determined by using ANOVA and post-hoc tests for multiple comparisons using SPSS 9.0 computer Software. Results were considered significant at $\mathrm{P}<0.05$.

\section{Results}

Isolated and cultured undifferentiated MSCs reached $70-80 \%$ confluence at 14 days. They were identified by their fusiform fibroblast likestructure and gene expression of CD29 (Figure 1). MSCs improve the kidney function: As shown in Table 1 results of the present study showed that mesenchymal stem cells have a significant improvement in kidney function, serum $\mathrm{Na}$ concentration increased significantly in CRF group $(\mathrm{P}<0.001)$ in comparison to control group. However after MSC injection, serum $\mathrm{Na}$ concentration significantly decreased $(\mathrm{P}<0.001)$. Regarding serum $\mathrm{K}$, urea and 24hour urinary albumin, their concentration was significantly elevated in CRF group ( $\mathrm{P}=0.002)$. However, following MSC injection, their levels started to decrease significantly $(\mathrm{P}=0.03)$ compared to the CRF group. However serum creatinine showed significant elevation in CRF group compared to the control group. MSCs infusion did not affect significantly serum creatinine. MSCs ameliorate the systolic blood pressure (SBP): As regards the systolic blood pressure (Table 1), there was a significant decrease as well as normalization of its level in CRF/MSCs group as compared to CRF group and to control group respectively.

\section{Homing of labeled mesenchymal stem cells in renal tissues}

Labeled MSCs with GFP were detected using fluorescent microscope in unstained renal tissues in CRF/MSCs group only, confirming that these cells were actually seeded into the renal tissues as shown in (Figure 2).

\section{Mesenchymal stem cells affect the kidney morphologically}

Histopathological examination of kidney tis- sue following MSC injection showed, dense interstitial, periglomerular, perivascular and diffuse interstitial tissue infiltrates (renal cortex), renal medulla shows medullary tubules with dilated lumina and focal hydropic degenerative changes. MT shows dense fibrosis invaded by a dense collection of MSC and endarteritis obliterans. (Figures 3 and 4).
Mesenchymal stem cells and gene expression of anti-inflammatory and antiapopotic markers

As regards gene expression, Bcl-2 and b-FGF genes were decreased in CRF group, whereas, its band density was significantly increased in CRF/MSCs rat groups. Bcl-2 and b-FGF DNA

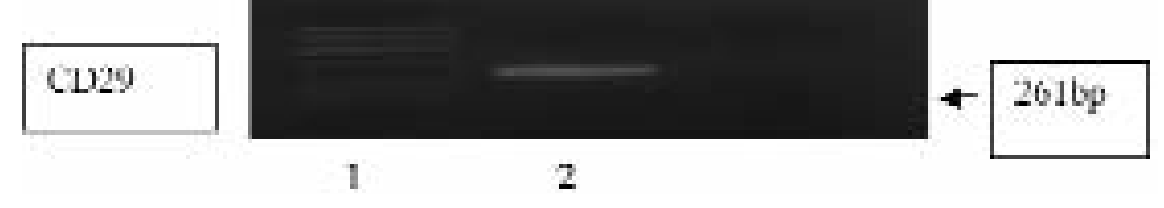

Figure 1. UV transilluminated agarose gel of polymerase chain reaction (PCR) product of CD29 gene in mesenchymal stem cells culture. Lane1, PCR marker; Lane 2, CD29 gene in MSCs culture.

Table 1. Serum Na, K, urea, creatinine, $24 \mathrm{~h}$ urinary albumin and SBP (mean \pm SD) among the studied groups.

\begin{tabular}{lrcc} 
Measured parameters & $\begin{array}{c}\text { Control } \\
\text { Mean } \pm \text { SD }\end{array}$ & $\begin{array}{c}\text { CRF } \\
\text { Mean } \pm \text { SD }\end{array}$ & $\begin{array}{c}\text { CRF/MSC } \\
\text { Mean } \pm \text { SD }\end{array}$ \\
$\mathrm{Na}(\mathrm{mEq} / \mathrm{L})$ & $134 \pm 4.28$ & $152 \pm 5.69^{*}$ & $142 \pm 4.78^{\circ}$ \\
$\mathrm{K}(\mathrm{mEq} / \mathrm{L})$ & $3.7 \pm 0.44$ & $5.5 \pm 0.68^{*}$ & $4.8 \pm 0.57^{* \circ}$ \\
\hline Urea $\mathrm{mg} / \mathrm{dL})$ & $42 \pm 4.74$ & $68.8 \pm 13.83^{*}$ & $49.1 \pm 5.11^{\circ}$ \\
Creatinine $(\mathrm{mg} / \mathrm{dL})$ & $0.198 \pm 0.08$ & $1.02 \pm 0.55^{*}$ & $0.43 \pm 0.1^{*}$ \\
\hline Urinary albumin $(\mathrm{mg} / 24 \mathrm{~h})$ & $0.08 \pm 0.02$ & $29.4 \pm 6.8^{*}$ & $5.4 \pm 0.63^{* \circ}$ \\
SBP $(\mathrm{mm} \mathrm{Hg})$ & $100.8 \pm 4.21$ & $141.6 \pm 4.45^{*}$ & $118 \pm 4.05^{\circ}$ \\
\hline
\end{tabular}

* Significant $\mathrm{P}$ as compared to group $1(\mathrm{P}<0.05)$; ${ }^{\circ}$ significant $\mathrm{P}$ as compared to group $2(\mathrm{P}<0.05)$.

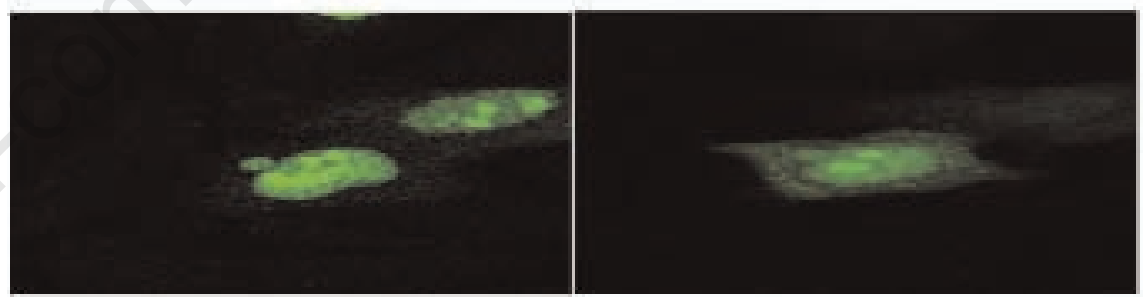

Figure 2. Confocal laser imaging showed strong green auto fluorescence appear in kidney tissue after mesenchymal stem cells (MSCs) injection. Arrows indicate positive signals for fluorescence of labeled MSCs in renal tissues.

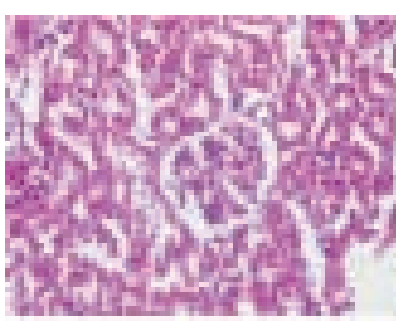

A

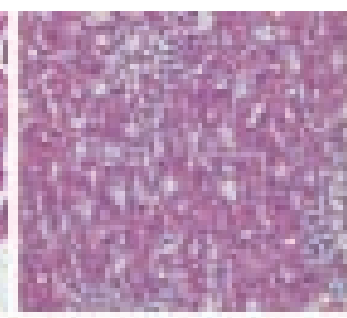

in

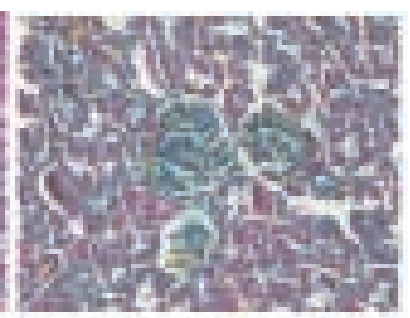

E

Figure 3. A) Photomicrographs of kidney tissue (cortex) from chronic renal failure (CRF) rat group stained with Hematoxylin and Eiosin renal cortex, B) renal medulla and C) masson trichrome cortex, showing increased cellularity and congestion of the glomeruli in renal cortex, medulla shows atrophic tubules and hyaline degenerative changes. 
band density quantification were demonstrated at Table 2. On the other hand, Sry gene that was used as Y chromosome marker was expressed in CRF/MSCs rat group only (Figure 5).

\section{Discussion}

Bone marrow-derived stem cells contribute to cell turnover and repair in various tissue types, including the kidneys. ${ }^{11,28}$ MSCs are attractive candidates for renal repair, because nephrons are of mesenchymal origin and because stromal cells are of crucial importance for signaling, leading to differentiation of both nephrons and collecting ducts. ${ }^{29}$ MSCs commonly are defined as bone marrow-derived fibroblast-like cells, which despite the lack of specific surface markers can be selected by their adherence characteristics in vitro and which have the ability to differentiate along the three principal mesenchymal lineages: osteoblastic, adipocytic, and chondrocytic. ${ }^{30,31}$ In the present study, bone marrow derived mesenchymal stem cells were isolated from male rats, grown and characterized by their adhesiveness and fusiform shape and by detection of CD 29, one of surface marker of rat mesenchymal stem cells and were used to detect their possible antiinflammaory and antiiapoptotic role in amelioration of renal function in experimental model of chronic renal failure.

In the current study $5 / 6$ nephrectomy method was applied to induce CRF in the studied rats, the assessment of kidney functions which showed significant elevation of urea, creatinine and $\mathrm{K}$ levels occurred as well as significant increase in serum $\mathrm{Na}$ level.

Significant elevation of systolic blood pressure (which can be either a cause or a consequence of chronic kidney disease (CKD) rapidly developed compared to the control group. These results are in agreement with these of Fleck et $a{ }^{18}{ }^{18}$ who found that the functional parameters clearly indicated the development of CRF following 5/6 nephrectomy.

The results of the present work showed that most of the examined parameters had significant improvement following MSCs injection compared to the renal failure group. $\mathrm{Na}, \mathrm{K}$, urea, Bcl-2, bFGF, SBP and urinary albumin showed statistically significant improvement following MSC injection. However, creatinine was the sole examined parameter that failed to reach statistical significance throughout the experiment duration, with, probably needing more time to do. Similar result was obtained by Kunter et al. ${ }^{32}$ in their study, creatinine also failed to reach statistical significance with. Improvement of those parameters goes in accordance with Caldas et al., ${ }^{33}$ whose study showed in addition significant reduction in creatinine level.

Histopathological examination of renal tissue samples showed dense interstitial, periglomerular, perivascular and diffuse interstitial tissue infiltrates. MT showed dense fibrosis invaded by a dense collection of MSCs as indicated by autofluorescence appears in kidney tissue after MSCs injection. Those were examined with H\&E stain, that is a more sensitive detector regarding cellular infiltration, finally with Mason Dichromate, which is a better detector of collagen fibers hence, fibrosis and scaring. These findings agreed with those of Li et al., ${ }^{34}$ who recorded similar perivascular and periglomerular infiltration, in addition, they reported cell fusion, with occurrence of binucleated cells. Similar findings were obtained by Hauger et al. ${ }^{35}$ who used MRI to detect homing of donors' cells into the injured kidneys.

Following stem cell injection, those donors' cells could be detected in recipient failing kidneys by using PCR technique as evident by detection of Sry gene in female rat that received MSCs derived from male rats and by autofluorescence that appeared in kidney tissue after MSCs injection. Fusion or transdifferentiation, this could not be answered in this

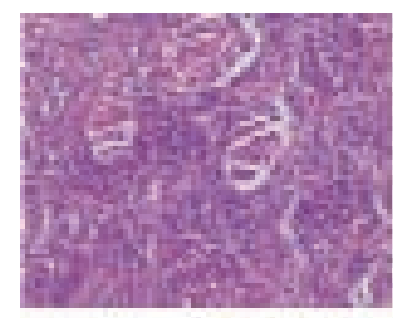

A

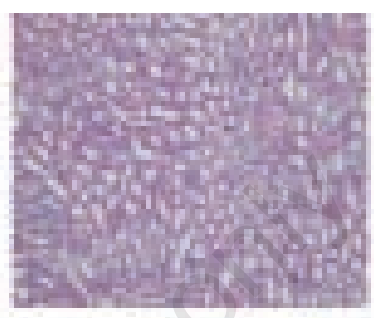

$B$

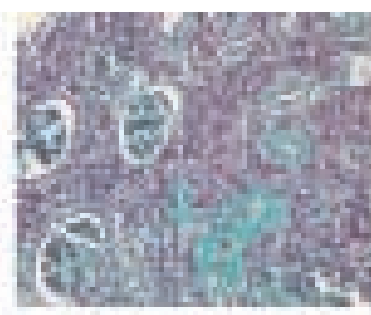

I-

Figure 4. A) Photomicrographs of kidney tissue (cortex) from chronic renal failure/mesenchymal stem cell (CRF/MSC) rat group stained with Hematoxylin and Eiosin cortex, B) medulla and $\mathrm{C}$ ) and masson trichrome cortex, showing dense interstitial tissue infiltrate by periglomerular, perivascular and diffuse interstiial tissue infiltrates.

Table 2. Band density quantification for Bcl-2 and b-FGF genes expression.

\begin{tabular}{lcc} 
Group & Bcl-2 $($ mean \pm SD $)$ & b-FGF $($ mean \pm SD $)$ \\
Control & $0.472 \pm 0.019^{\circ}$ & $0.549 \pm 0.029^{\circ}$ \\
CRF & $0.128 \pm 0.003$ & $0.283 \pm 0.008$ \\
\hline CRF/MSCs & $0.462 \pm 0.021^{\circ}$ & $0.621 \pm 0.032^{\circ}$
\end{tabular}

${ }^{\circ}$ significant $\mathrm{P}$ as compared chronic renal failure (CRF) group to other groups $(\mathrm{P}<0.05)$.

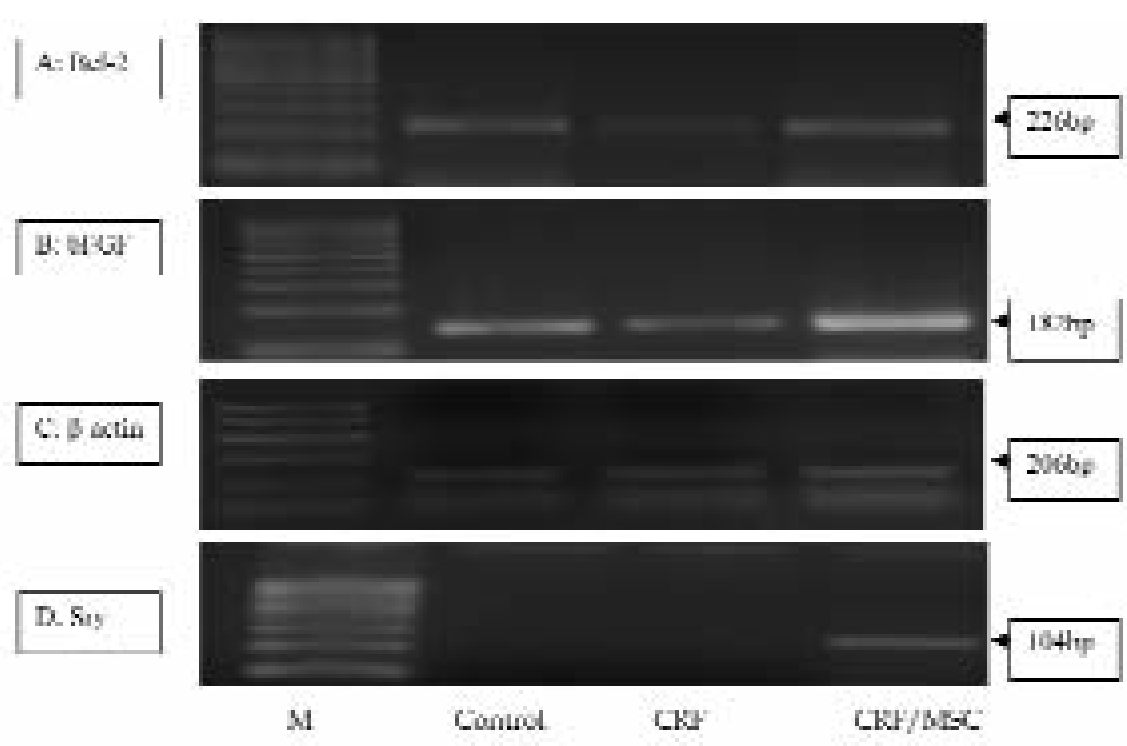

Figure 5. A) UV transilluminated agarose gel of polymerase chain reaction (PCR) products of Bcl-2, B) b-FGF, C) $\beta$-actin D) and Sry genes in different studied groups. 
study. However, both techniques definitely proved that those cells were able to maintain high population all through the study, in other words, for 4 weeks following MSC injection. These results agree with those of Li et al. ${ }^{34}$ who showed 50\% replacement of proximal tubular cells with donor cells. These results also agree with Rookmaaker et al. ${ }^{36}$ who declared that bone-marrow-derived cells might home to injured glomerular endothelium, differentiate into endothelial cells, and participate in regeneration of the highly specialized glomerular microvasculature. In addition, they confirmed previous observations that bone-marrowderived cells can replace injured mesangial cells. ${ }^{37}$ Also Tögel et al. ${ }^{38}$ stated that infused MSC were detected in the kidney only early after administration and were predominantly in glomeruli and attached in peritubular capillaries.

However, those results disagree with some other studies; Li et $a l^{34}$ and Duffield et al. ${ }^{39}$ who disagreed on whether there was evidence for transdifferentiation, but both concluded that while bone marrow derived cells (BMDC) recruitment occurs, repair is predominantly elicited via proliferation of endogenous renal cells.

Duffield et al. ${ }^{39}$ state that BDMC contribute a regenerative cytokine environment that may be important in the resulting functional repair.

Similarly, it was found that bone marrowderived stem cells seemed to contribute relatively small numbers of cells (3-22\%) to regenerating renal tubular ${ }^{40}$ and glomerular cell populations ${ }^{11}$ that is, the majority of reparative cells were derived from intrinsic kidney cells.

Regardless the cause, whether it's MSC differentiation, fusion or merely cytokine induced renal improvement; following MSC injection, the results of the present work showed increase in bFGF and Bcl-2 gene expression in renal tissues. Several studies stated that After $24 \mathrm{~h}$ of MSCs infusion, only exceptionally scarce numbers of MSCs were found in the kidney, a pattern that essentially rules out the possibility that significant numbers of infused MSC are retained in the kidney where they could physically replace lost kidney cells by transdifferentiation. This conclusion is furthermore supported by the fact that there were no intrarenal transdifferentiation events of MSC within 3 days of administration, whereas occasional MSC-derived capillary endothelial cells were identified only after 5-7 days. From this, it could be deduce that the mechanisms that mediate the protective effects of MSC must be primarily paracrine, as implied by their expression of several growth factors such as HGF, VEGF, and IGF-I, all known to improve renal function in ARF, mediated by their antiapoptotic, mitogenic and other cytokine actions. Collectively, these as yet incompletely defined paracrine actions of MSC result in the renal down-regulation of proinflammatory cytokines IL-1- $\beta$, TNF- $\alpha$, and IFN$\gamma$, as well as iNOS, and up-regulation of antiinflammatory and organ-protective IL-10, ${ }^{41}$ as well as bFGF, TGF- $\alpha$, and Bcl-2. The lack of renoprotection obtained by infused fibroblasts may be due, at least in part, to the fact that MSC exhibit a comparatively higher expression of VEGF, HGF, and IGF-I, therefore suggesting that the combined delivery, by MSC, of these factors appears to result in superior renoprotection than that obtained with the growth factors that are more highly expressed by fibroblasts (EGF, HB-EGF, BMP-7, bFGF).

In consideration of the role of endogenous bone marrow MSCs, a possible approach could also be the stem cells mobilization. However, the possible effects of BM-recruited cells and of inflammatory cells in this experimental setting require further investigation. Currently, the most promising approach is considered to be the administration of in vitro expanded MSC applied to acute tubular and glomerular injury. Injected MSCs were shown to home to the injured kidney and to accelerate morphological and functional regeneration, possibly by a paracrine or even endocrine mechanisms, although their engraftment and transdifferentiation was not observed in the majority of the studies. A major role in the effect of MSCs has been attributed to the production of growth factors and cytokines with immunosuppressive, antiinflammatory, anti-apoptotic and proliferative effects. Several clinical trials have been designed or are in progress to evaluate the effect of MSCs administration in renal transplantation, acute renal injury or chronic allograph nephropathy (www.clinicaltrial.gov). The effect of MSC administration in chronic renal damage still deserves investigation. ${ }^{42}$

To conclude, this study proved that the impairment in renal functions that associates CRF could be significantly corrected by single intravenous injection of donor's stem cells. Stem cells reach the injured kidney through its arterial supply and start infiltration within few days and sooner, improvement of renal functions start. The mechanism of action of those cells might be not only through improvement of healing process but also through antiinflammatory and antiapoptotic paracrine actions.

\section{References}

1. Ysebaert DK, De Greef KE, Vercauteren $\mathrm{SR}$, et al. Identification and kinetics of leukocytes after severe ischaemia/reperfusion renal injury. Nephrol Dial Transplant 2000;15:1562-74.

2. Humes HD. Bioartificial kidney for full renal replacement therapy. Semin Nephrol
2000;20:71-82.

3. Stadnyk AW. Cytokine production by epithelial cells. FASEB J 1994;8:1041-7.

4. Humes HD. Cell therapy: leveraging nature's therapeutic potential. J Am Soc Nephrol 2003;14:2211-3.

5. Krause DS. Plasticity of bone marrowderived stem cells. Gene Ther 2002;9:7548.

6. Ferrari G, Cusella-De Angelis G, Coletta M, et alF. Muscle regeneration by bone marrow-derived myogenic progenitors. Science 1998;279:1528-30.

7. Hess DC, Hill WD, Martin-Studdard A, et al. Bone marrow as a source of endothelial cells and NeuN-expressing cells after stroke. Stroke 2002;33:1362-8.

8. Orlic D, Kajstura J, Chimenti S, et al. Bone marrow cells regenerate infarcted myocardium. Nature 2001;410:701-5.

9. Drewa T, Joachimiak R, Kaznica A, et al. Bone marrow progenitors from animals with chronic renal failure lack capacity of in vitro proliferation. Transplant Proc 2008;40:1668-73.

10. Gupta S, Verfaillie C, Chmielewski D, et al. A role for extra renal cells in the regeneration, following acute renal failure. Kidney Int 2002;62:1285-90.

11. Poulsom R, Forbes SJ, Hodivala-Dilke K, et al. Bone marrow contributes to renal parenchymal turnover and regeneration. $\mathrm{J}$ Pathol 2001;195:229-35.

12. Grimm PC, Nickerson P, Jeffery J, et al. Neointimal and tubulointerstitial infiltration by recipient mesenchymal cells in chronic renal-allograft rejection. N Engl J Med 2001;345:93-7.

13. Uchimura H, Marumo T, Takase 0 , et al. Intrarenal injection of bone marrowderived angiogenic cells reduces endothelial injury and mesangial cell activation in experimental glomerulonephritis. J Am Soc Nephrol 2005;16:997-1004.

14. Abdel Aziz MT, Atta HM, Mahfouz S, et al. Therapeutic potential of bone marrowderived mesenchymal stem cells on experimental liver fibrosis. Clin Biochem 2007;40:893-9.

15. Abdel Aziz MT, Farid El-Asmer M, Haidara M, et al. Effect of bone marrow-derived mesenchymal stem cells on cardiovascular complications in diabetics rats. Med Sci Monit 2008;14:BR249-55.

16. El-Menoufy H, Aly LA, Aziz MT, et al. The role of bone marrow-derived mesenchymal stem cells in treating formocresol induced oral ulcers in dogs. J Oral Pathol Med 2010;39:281-9.

17. Abdel Aziz MT, El Asmar FM, Atta H, et al. Efficacy of mesenchymal stem cells in suppression of hepatocarcinorigenesis in rats possible role of wnt signaling. J Exper Clin Cancer Res 2011;30:49. 
18. Mokbel A, El-Tookhy 0, Shamaa AA, et al. Homing and efficacy of intra-articular injection of autologous mesenchymal stem cells in experimental chondral defects in dogs. Clin Exp Rheumatol 2011;29:275-84.

19. Feng SW, Yao XL, Li Z, et al. [In vitro bromodeoxyuridine labeling of rat bone marrow-derived mesenchymal stem cells]. Di Yi Jun Yi Da Xue Xue Bao 2005;25:184-6.

20. Niki H, Hosokawa S, Nagaike K, Tagawa T. A new immunofluorostaining method using red fluorescence of PerCP on formalin-fixed paraffin-embedded tissues. J Immunol Methods 2004;293:143-51.

21. Fleck C, Appenroth D, Jonas P, et al. Suitability of $5 / 6$ nephrectomy (5/6NX) for the induction of interstitial renal fibrosis in rats--influence of sex, strain, and surgical procedure. Exp Toxicol Pathol 2006;57:195-205.

22. Choi S, Park M, Kim J, et al. The role of mesenchymal stem cells in the functional improvement of the chronic renal failure. Stem Cells Dev 2008;22:134-8.

23. Lloberas N, Cruzado JM, Torras J, et al. Protective effect of UR-12670 on chronic nephropathy induced by warm ischaemia in ageing uninephrectomized rats. Nephrol Dial Transplant 2001;16:735-41.

24. Bruckner JV, Ramanathan R, Lee KM, Muralidhara S. Mechanisms of circadian rhythmicity of carbon tetrachloride hepatotoxicity. J Pharmacol Exp Ther 2002;300: 273-81.

25. Janakat S, Al-Merie H. Optimization of the dose and route of injection, and characterisation of the time course of carbon tetrachloride-induced hepatotoxicity in the rat. J Pharmacol Toxicol Methods 2002;48:41-
4.

26. Inokuchi K, Futaki M, Dan K, Nomura T. Possible correlation of b3-a2-type bcr-abl messenger RNA defined by semiquantitative RT-PCR to platelet and megakaryocyte counts in Philadelphia-positive chronic myelogenous leukemia. Intern Med 1994;33:189-92.

27. Wang HS, Hung SC, Peng ST, et al. Mesenchymal stem cells in the Wharton's jelly of the human umbilical cord. Stem Cells 2004;22:1330-7.

28. Cornacchia F, Fornoni A, Plati AR, et al. Glomerulosclerosis is transmitted by bonemarrow-derived mesangial cell progenitors. J Clin Invest 2001;108:1649-56.

29. Anglani F, Forino M, Del Prete D, et al. In search of adult renal stem cells. J Cell Mol Med 2004;8:474-87.

30. Pittenger MF, Mackay AM, Beck SC, et al. Multilineage potential of adult mesenchymal stem cells. Science 1999;284:143-7.

31. Imai E, Ito T. Can bone marrow differentiate into renal cells? Pediatr Nephrol 2002;17:790-4.

32. Kunter U, Rong S, Djuric Z, et al. Transplanted mesenchymal stem cells accelerate glomerular healing in experimental glomerulonephritis. J Am Soc Nephrol 2006;17:2202-12.

33. Caldas HC, Fernandes IM, Gerbi F, et al. Effect of whole bone marrow cell infusion in the progression of experimental chronic renal failure. Transplant Proc 2008;40:853-5.

34. Li L, Truong P, Igarashi P, et al. Renal and bone marrow cells fuse after renal ischemic injury. J Am Soc Nephrol 2007;18: 3067-77.
35. Hauger 0, Frost EE, van Heeswijk R, et al. MR evaluation of the glomerular homing of magnetically labeled mesenchymal stem cells in rat model of nephropathy. Radiology 2006;238:200-10.

36. Rookmaaker MB, Smits AM, Tolboom H, et al. Bone-marrow-derived cells contribute to glomerular endothelial repair in experimental glomerulonephritis. Am J Pathol 2008;163:553-62.

37. Ito T, Suzuki A, Okabe M, et al. Application of bone marrow-derived stem cells in experimental nephrology. Exp Nephrol 2001;9:444-50.

38. Tögel F, Hu Z, Weiss K, et al. Administered mesenchymal stem cells protect against ischemic acute renal failure through differentiation-independent mechanisms. Am J Physiol Renal Physiol 2005;289:F3142.

39. Duffield JS, Park KM, Hsiao LL, et al. Restoration of tubular epithelial cells during repair of the postischemic kidney occurs independently of bone marrowderived stem cells. J Clin Invest 2005;7: 1743-55.

40. Kale S, Karihaloo A, Clark PR, et al. Bone marrow stem cells contribute to repair of the ischemically injured renal tubules. $\mathrm{J}$ Clin Invest 2003;112:42-9.

41. Deng J, Kohda Y, Chiao $\mathrm{H}$, et al. Interleukin-10 inhibits ischemic and cisplatin-induced acute renal injury. Kidney Int 2001;60:2118-28.

42. Bussolati B, Hauser PV, Carvalhosa R, Camussi G. Contribution of stem cells to kidney repair. Curr Stem Cell Res Ther 2009;4:2-8. 